\title{
USE-WEAR ANALYSIS OF FLINT ARTEFACTS FROM THE BARROWS OF THE CORDED WARE CULTURE IN ULÓW
}

\author{
KaTARZYNA PyŻEWiCZ
}

A u th o r's a d d r e s s: Institute of Archaeology, Adam Mickiewicz University in Poznań, Umultowska 89D, 61-614 Poznań, e-mail: pyzewicz@amu.edu.pl

$\mathrm{A} \mathrm{b} \mathrm{s} \mathrm{tra} \mathrm{ct.} \mathrm{As} \mathrm{part} \mathrm{of} \mathrm{the} \mathrm{interdisciplinary} \mathrm{research} \mathrm{conducted} \mathrm{in} \mathrm{the} \mathrm{settlement} \mathrm{microregion} \mathrm{in} \mathrm{the}$ area of Ulów in central Roztocze (south-east Poland), a complex of late Neolithic Corded Ware Culture barrows was discovered. Apart from numerous ceramic items, grave inventories included flint artefacts, some of which underwent use-wear analysis in order to identify their potential function, and production techniques. This paper presents detailed results of use-wear analysis of arrowheads, blade and flake specimens, and axes discovered in four barrows located at sites 3 and 4 in Ulów.

K e y w o r d s: use-wear analysis, flint artefacts, the Neolithic, Corded Ware Culture, Ulów, Roztocze Środkowe

\section{INTRODUCTION}

The use of lithics by the communities of the Corded Ware Culture inhabiting what are today Polish lands has not been fully explored, mainly due to the low number of use-wear examinations carried out so far. In the past years, the issue was addressed several times during the examination of artefacts from the graves of this culture located in Koniusza (Drobniewicz 1979), Zielona (WiniarsKa-KabaciŃsKa 2007, 2008), Dąbrowa Biskupia (BudzISzEwsKi et al. 2008) and Wilczyce (WŁodarczaK et al. 2016). Use-wear analysis of flint artefacts from these sites involved the examination of arrowheads, flake and blade forms, often intentionally retouched, and axes.

The goal of the presented research was to identify the function of flint tool-kits deposited in the four barrows at sites 3 and 4 in Ulów, Tomaszów Lubelski commune $^{1}$. The microscopic analysis focused on studying traces produced by manufacturing, hafting and usage. Additionally, the results of microwear studies were the basis for comparative research with the use-wear analysis involving flint artefacts obtained

1 The exact location of the site and description of the field works conducted there were introduced in this volume by Barbara Niezabitowska-Wiśniewska. 
from other graves associated with the Corded Ware Culture located on Polish territory. The data are the part of the broader interdisciplinary research into the settlement complex in the area of Ulów in central Roztocze.

\section{MATERIALS AND METHODS}

For in-depth use-wear analysis, artefacts from four barrows were selected. The research involved the examination of all flint artefacts from barrows I, II and III at site 3 , and barrow II located at site 4 . Most numerous among these specimens are flint arrowheads, yet retouched blades and axes were also recorded. The sets of these tools were obtained from barrow I at site 3 (six arrowheads, one retouched blade, one axe, and random objects - one arrowhead and one bipolar flake), barrow III at site 3 (one arrowhead, one retouched blade and one axe), and barrow II at site 4 in Ulów (six arrowheads, one retouched blade and two axes). Analysis also included two flakes, two splintered pieces, one burin, one end-scraper, one blade and one chip from barrow II at site 3. The artefacts were made of Cretaceous flint of good quality, most likely Volhynian flint. Unfortunately, in several cases the identification of the raw material was impossible due to the burning of the pieces.

Use-wear analysis was conducted with a Nikon LV150 metallographic microscope. The surfaces of artefacts were observed at magnifications of $50 \times, 100 \times$, and $200 \times$. The flints were cleaned with a detergent in warm water, and acetone. Microscopic analysis was carried out in order to find potential use-wear and hafting traces, and to identify the marks made by tools used in the process of knapping.

The microscopic traces were interpreted on the basis of the literature (e.g. Keeley 1980; Moss 1983; Vaughan 1985; Anderson-Gerfaud 1988; Juel Jensen 1988, 1994; Levi-Sala 1993, 1996; Korobkowa 1999; Malecka-KuKawKa 2001; Rотs 2010). Additionally, the interpretation of postdepositional, technological, hafting and usage traces refers to the results of experimental research conducted by the author of this paper in previous years. The documentation of these studies is kept at the Institute of Archaeology, Adam Mickiewicz University. These experimental studies are the part of the wider project which has been conducted at the Archaeological Museum in Biskupin. Detailed information is presented in separate publications, including: Katarzyna Pyżewicz (2013b) - technological, hafting and usage traces on the diverse tools, Pyżewicz and Rozbiegalski (2012) - traces associated with lithic strike-a-lights, Katarzyna PyŻewicz, Witold Grużdź (2014) - storage and hafting traces on projectiles, Katarzyna Pyżewicz, Witold Grużdź, Piotr DMochowski (2016) - technological, hafting traces and usage of flint axes, RAdosŁaw Ł. KUBICKI (2015) - technological traces on axes. 


\section{RESULTS}

Use-wear analysis of flint artefacts from Ulów revealed, above all, intense hafting traces, with use-wear signs appearing only in isolated cases. However, despite attempts to do so it was impossible to characterise tools which were used in flint production process, both during detachment of blanks and later in final retouching. Such distinguishing features were not preserved on the analysed flint surfaces.

Postpositional effects visible on lithic artefacts are mostly limited to the microscopic traces occurring in a very initial form. Therefore, usually the microwear analysis was not impeded by these factors. Only few artefacts were excluded from further analysis due to contact with fire. These forms have surfaces that exhibit change of colour and flint structure that resulted in blurring of the potential use-wear traces. It is difficult to determine the causes of overheating of individual specimens. It could be associated with the accidental contact with fire, but it is not excluded that in individual cases they are the effect of intentional human activity. Some other artefacts are characterized by the occurrence of bright spots which are appearing individually or in groups on a limited surface area. These types of traces can be interpreted both as a result of natural and mechanical factors, for example some of them can be an effect of the contact of lithic tools with the hafts (Levi-SALA 1993: 412-416; 1996: 32, 70, 71; HowARD 1999; Rots, VermeERSCH 2004: 161, 162; Rots 2010: 34 and next).

\section{Barrow I from site Ulów 3}

All artefacts obtained from the central barrow grave have marks connected with their hafting and storage. The surfaces of six examined flint arrowheads do not show any indications on the macro or microscopic level which would indicate their use as elements of projectile weapons, or for other purposes. However, on the surfaces of five arrowheads, around their barbs and tips, clear microscopic traces were recorded (Fig. 1). The use-wears on the specimens are visible in the form of polishes occurring on both sides, mainly on protruding parts. These traces are dull, partly slightly "greasy" and penetrate the flint's microstructure. The polishes are accompanied by rounding of protruding parts of tips and barbs. The presented use-wear traces are similar to those which arise from contact with hide, and most likely occurred as a result of transport or long-term storage in containers made of skin. The last examined arrowhead is characterised only by delicate polishes on both surfaces, which, due to their undeveloped form, are not distinctive.

Another artefact, a retouched blade, is distinguished by traces similar to those found on the arrowheads. Such marks are found on protruding parts of both surfaces and along the edges, and most likely developed as a result of contact with soft organic material (hide?) (Fig. 2: 1, A). It should be acknowledged that this item was also stored in a container of some type.

Particularly intense hafting traces were observed on the surface of the axe (Fig. 2: 2, B-D). They resulted from contact with soft organic materials - hide and plant fibre (?). These traces appear primarily in the form of polishes overlapping protruding parts - ridges and the edges of the axe, as well as extending to the lower parts. Usually, 

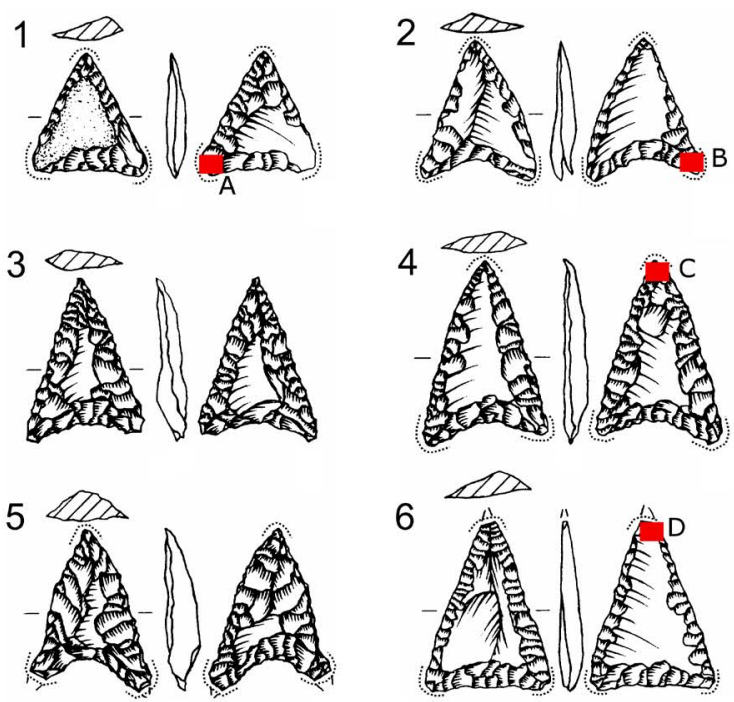

\section{0} $5 \mathrm{~cm}$
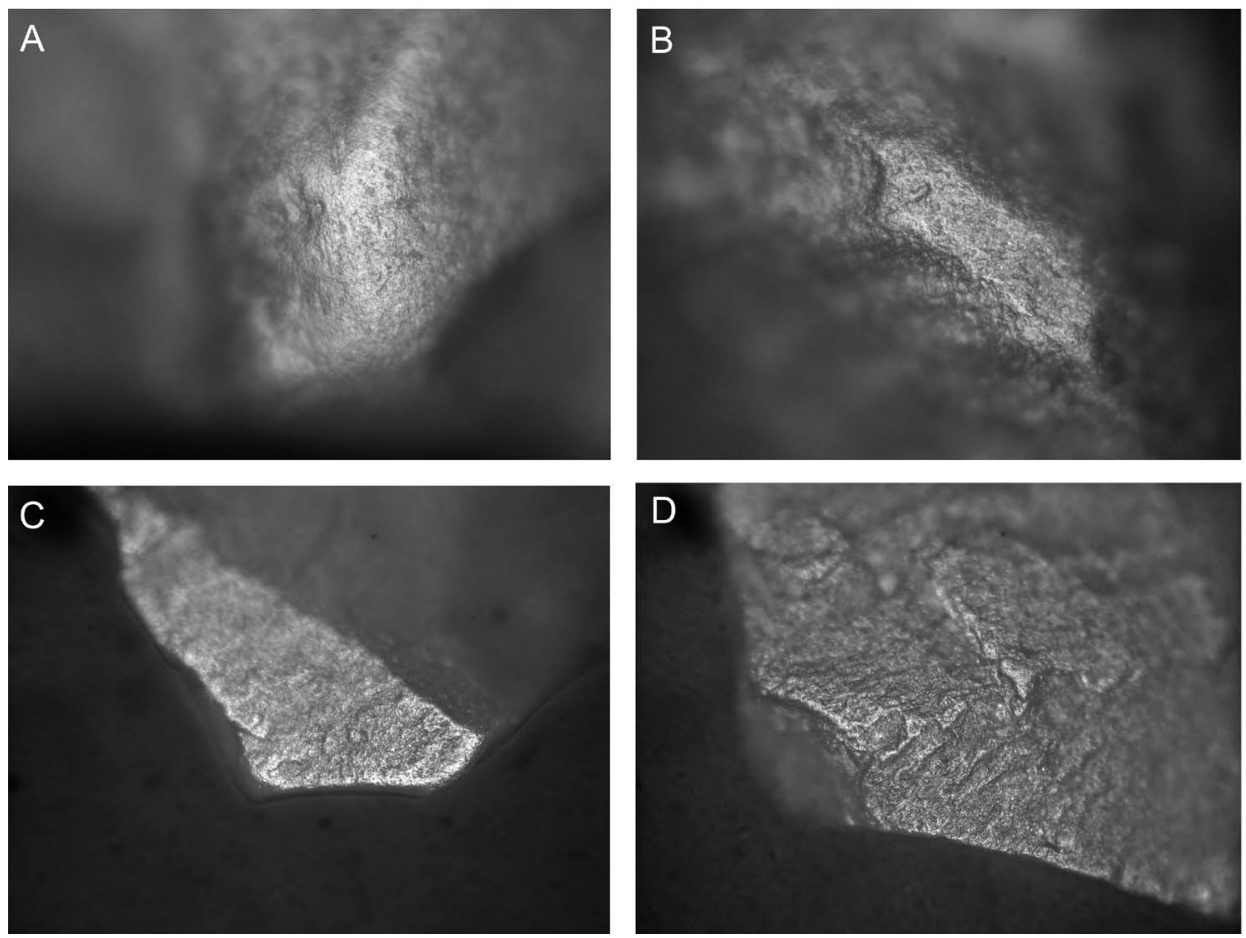

Fig. 1. Ulów, site 3. Flint artefacts from barrow I. 1-6 flint arrowheads. A-D - traces of contact with hide (storage/transport). A-B $-200 \times$ magnification; C-D $-100 \times$ magnification. Draw. T. Wiśniewski, phot. K. Pyżewicz. Key (for all figures): dotted line - hafting, storage or transport traces; dashed line - use-wear traces; squares - area shown on microscopic photo 

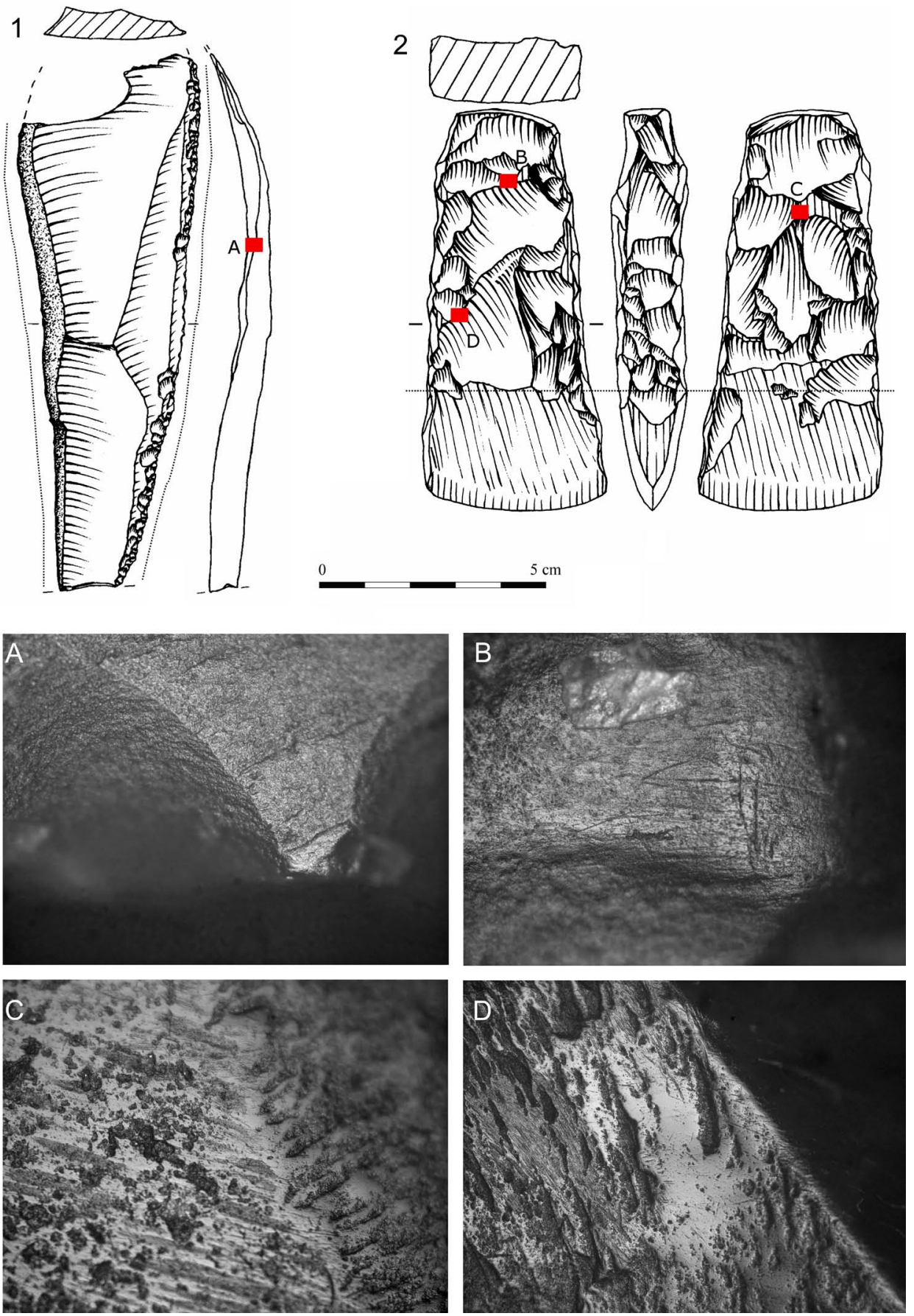

Fig. 2. Ulów, site 3. Flint artefacts from barrow I. 1 - retouched blade; 2 - axe. A - traces of contact with hide (storage/transport); $\mathrm{B}$ - traces of contact with hide (hafting); $\mathrm{C}$ - traces of contact with hide /plant fibre (hafting) and technological linear traces; D - bright spot (hafting or postdepositional traces). A-B $100 \times$ magnification; C-D $-50 \times$ magnification. Draw. T. Wiśniewski, phot. K. Pyżewicz 
these traces resemble marks created during the intense contact of the artefact with the hide. They are dull and not very bright. Polishes usually penetrate the lithic microstructure, although there are some unpolished areas. In addition, protruding parts are rounded. The surface which is covered by hafting traces is in some parts characterized by polishes which are very bright and flat and resemble those that are created during contact with the plant fibre. The presented hafting traces reach about two-thirds of the length of the axe, and the extension of the haft roughly coincides with the end of the polished part. This means that the flint tool was deeply stuck in an organic haft. No use-wear traces were recorded, which might indicate that the axe might have been polished before being placed in the grave or it was not used. A quite problematic is the interpretation of the presence of bright spots in the area where mentioned hafting traces appear. Traces of this type can be a result of postdepositional factors (i.a. LÉVISALA 1993: 412-416, 1996: 32; HowARD 1999) or direct contact of the lithic tool with the haft, most probably made of hard material (i. a. RoTs 2003, 2008a, b, 2009; Rots, Vermeersch 2004: 161, 162). Additionally, based on the experimental tests related to the forming of the experimental lithic axes, it should be concluded that microscopic traces - bright spots, can be created during the grinding process (KUBICKI 2015; PyżEwicz et al. 2016).

Barrow I contained two other specimens, which were classified as random. The first, an arrowhead, is characterised by signs of storage analogical to the above-mentioned ones. The second one - splintered piece, is not covered by any microwear traces.

\section{Barrow II from site Ulów 3}

Flint artefacts obtained from several features located within barrow II were to a high degree burnt. Thus, it was impossible to conduct microscopic analysis of all specimens. As a result of high temperature, two splintered pieces and one end-scraper were excluded from further use-wear analysis. Four other artefacts, namely a partly broken blade, a flake, a bipolar flake and a chip do not bear microscopic traces. Worthy of note is a retouched flake from one of the features (Fig. 3: 2), which shows potential traces of storage. On both sides of the artefact - on the protruding parts like ridges and some parts of edges, are visible polishes in the initial form. Additionally, these parts are rounded. Due to undeveloped form of polishes it is not certain if these traces are resulted from storage or postdepositional factors. Interesting results were obtained from use-wear analysis of a burin of a Late Palaeolithic type (as is suggested by Barbara NieZabitowsKa-WiśniewsKa and TADEUSZ WiŚNIEWSKI 2011: 357) obtained from the backfill of one of the graves. The lower part of the artefact shows intense macroscopic and microscopic traces, which indicate that it was used to make a fire (Fig. 3: 1, A). This part of the tool is rounded and covered by polishes which are very bright, "metallic", and abrasive. Within the area of polishes groups of linear traces (associated with trajectory of movements) are observed. It is possible that the object is an example of reutilisation - Neolithic communities used the Palaeolithic object as a strike-a-light. 

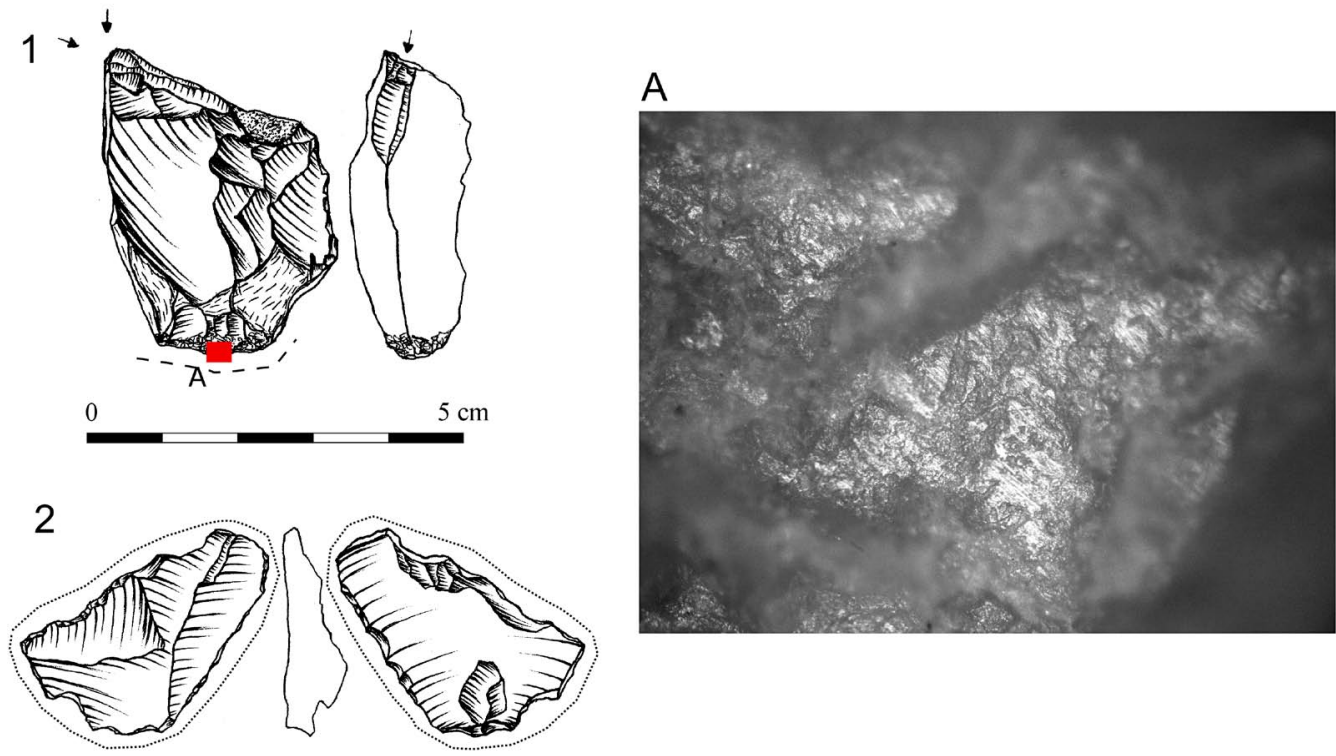

Fig. 3. Ulów, site 3. Flint artefacts from barrow II.1 - burin; 2 - retouched flake. A - traces of using the specimen as a strike-a-light. A - 100× magnification. Draw. T. Wiśniewski, phot. K. Pyżewicz

\section{Barrow III from site Ulów 3}

Among the inventory of barrow III, which included a central barrow grave with a feature of the Corded Ware Culture sunk into it, were a retouched blade and an axe (an arrowhead was burnt). The retouched blade bears delicate traces of storage/hafting which stretch along both side edges and appear on protruding ridges (Fig. 4: 1, A). The morphology of observed polishes is analogical to the traces visible on blade from barrow I. The second artefact - the lithic axe is covered by the intense traces of a haft made of organic materials, including plant fibre and hide. The characteristics of polishes and their localization is similar to these observed on axe from barrow I. As with an axe from barrow I, the haft also coincides to a large extent with the end of the polished part of the blade, yet in this case the haft reached more or less half of the tool's length. Additionally, the axe is distinguished by microchips, linear traces located transverse to the working edge, and very bright, smooth polishes visible on the blade, which most likely resulted from wood processing, probably chopping (Fig. 4: 2, B-D).

\section{Barrow II from site Ulów 4}

The artefacts for use-wear analysis mainly come from the central barrow grave. As a result of microscopic analysis of six arrowheads, it should be acknowledged that the marks on these forms are very similar to those of the bifacial forms from barrow I at site 3 (therefore the detailed characteristic is omitted), and have an analogical location (Fig. 5). Five flint artefacts show distinct marks - polishes and rounded protruding parts of barbs and tips. Such traces are usually resulting from contact with hide, yet 

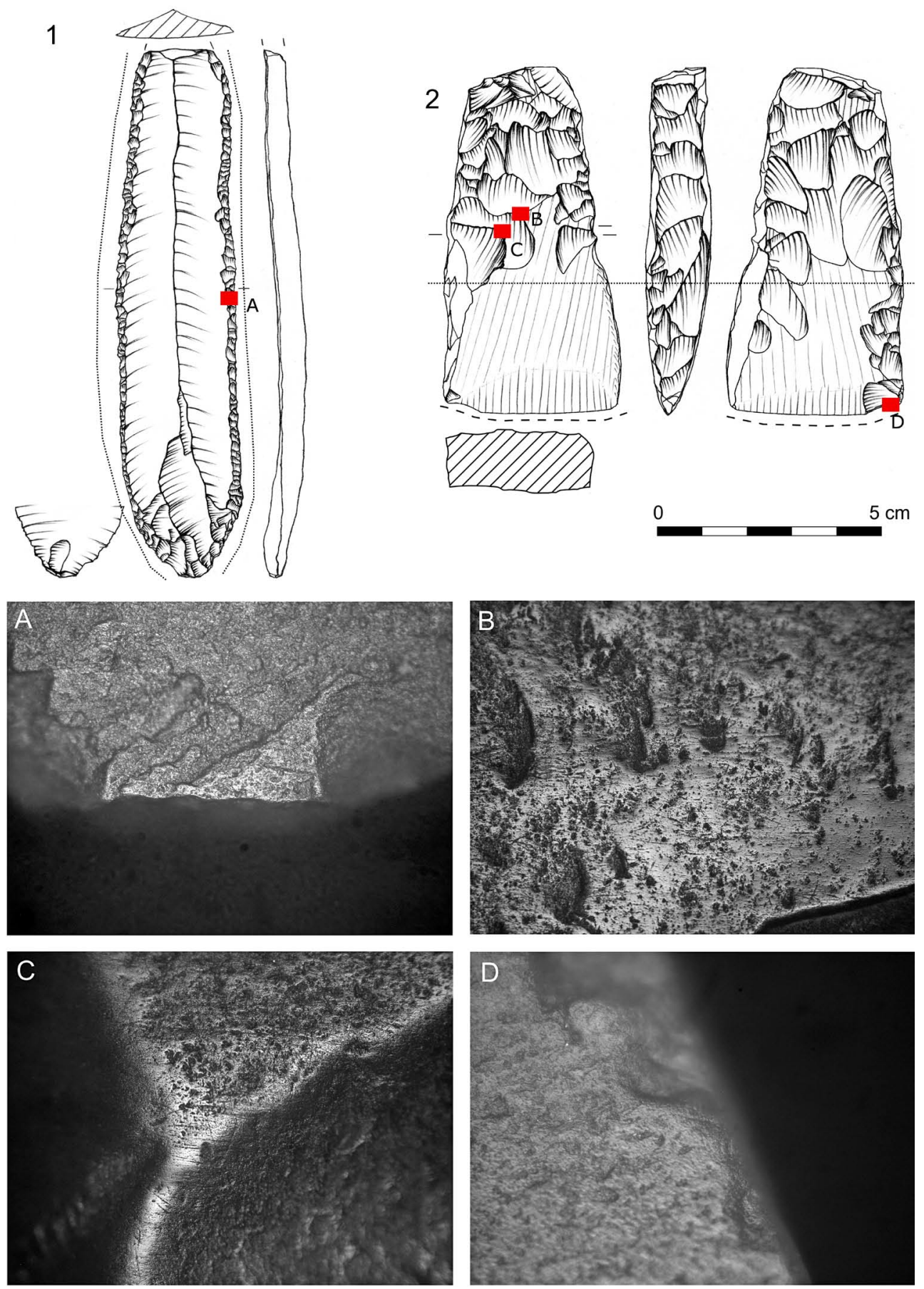

Fig. 4. Ulów, site 3. Flint artefacts from barrow III. 1 - retouched blade; 2 - axe. A - traces of contact with hide /plant fibre (storage/transport); B-C - traces of contact with hide /plant fibre (hafting); D - traces of wood chopping. A $-100 \times$ magnification; $\mathrm{B}-\mathrm{C}-50 \times$ magnification; $\mathrm{D}-200 \times$ magnification. Draw. 

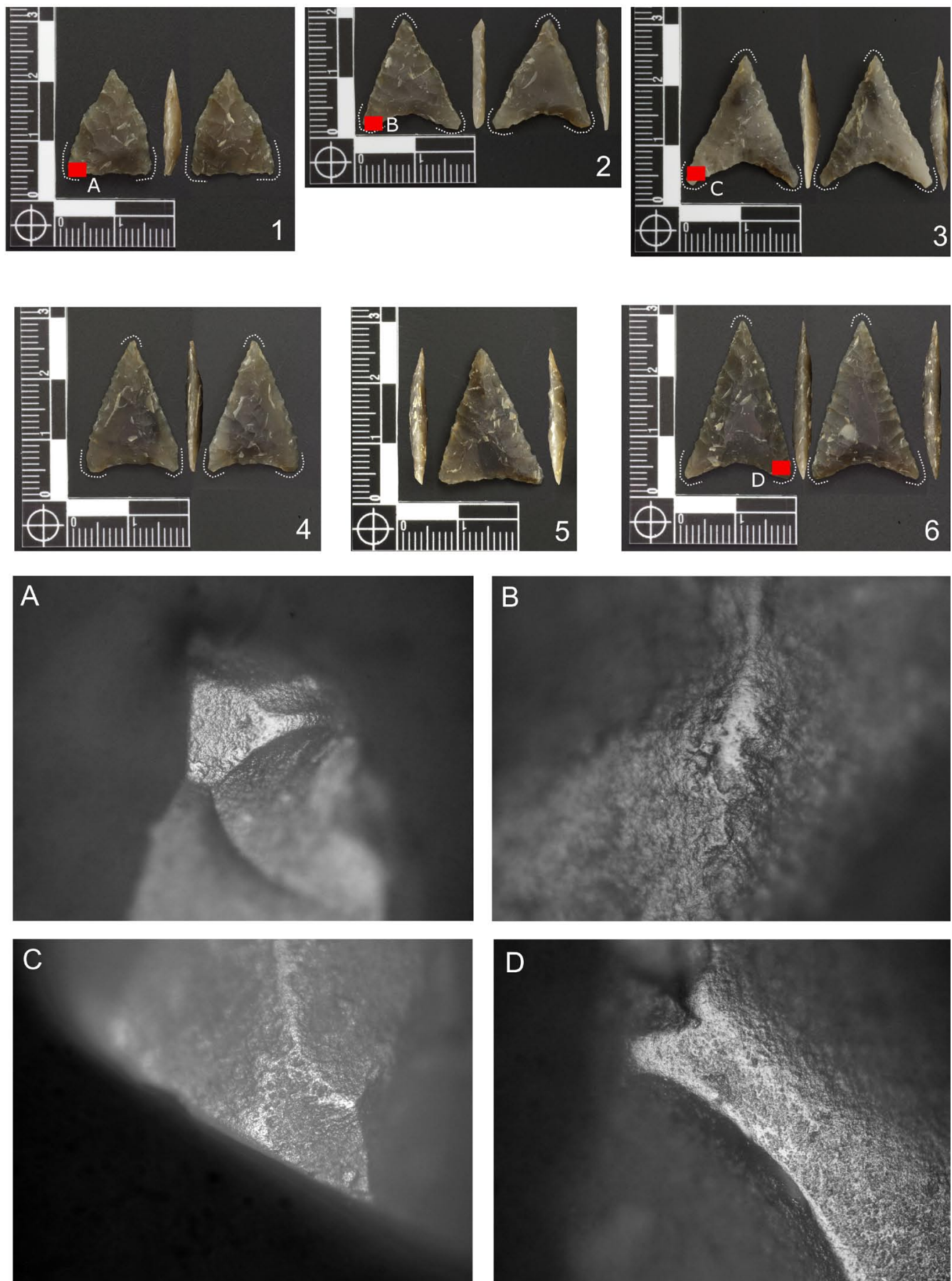

Fig. 5. Ulów, site 4. Flint artefacts from barrow II. 1-6 flint arrowheads. A-D - traces of contact with hide (storage/ transport). A, C-D - 100× magnification; B - 200× magnification. Phot. T. Wiśniewski, K. Pyżewicz 
in two cases there are additional marks which might suggest plant fibre origin. Thus, it should be acknowledged that arrowheads were stored in organic containers made of hide and/or plant fibre for an extended period of time. The last bifacial artefact does not reveal similar traces, but has delicate, uncharacteristic polish spots on the protruding parts of both surfaces. To sum up, it can be stated that the objects were likely to have been stored for a long time rather than used. The retouched blade which underwent microscopic analysis bears interpenetrating traces, the origin of which is connected with contact with hide - polishes which are dull, partly slightly "greasy" and penetrate the flint's microstructure (Fig. 6: 1, A). Some of the observed polishes which are very bright and flat are associated with plant fibre. These two types of polishes overlap and stretch along both longer edges and are at least partly connected with the way the blade was stored. It is conceivable that some traces of plant origin result from short-term processing of this material, for they accumulated in the proximal part of one of the longer edges. However, they are not developed enough to state this with certainty. Another piece, a slender axe, bears numerous marks, similar to those of an axe from barrow I and III at site 3 (Fig. 6: 2, B-D). While its blade shows usewear traces connected with wood processing, its central part and blunt end were set in a haft made from soft organic materials, such as hide and plant fibre. It is possible, that additional traces - bright spots, which were noticed in the same area as mentioned hafting traces are resulted from the contact with the hard material (or it is an effect of postdepositional or technological factors). Use-wear analysis was also carried out for another artefact, which was obtained from a feature sunk into a central barrow grave. It is a small axe (Fig. 7). Like the above-mentioned axes, the artefact was intended for intense woodwork activities. Distinct hafting traces on the blade signify a haft with an arched end. Extremely intense hafting traces - analogical to those presented above, but more intensive, indicate the use of plants and hide.

\section{DISCUSSION}

The above-mentioned results of use-wear analysis indicate that individual types of objects deposited in graves as grave goods were treated in a similar way. Two sets of arrowheads obtained from two graves (barrow I at site 3, and barrow II at site 4) do not bear traces of use. Obviously, it cannot be ruled out that they were used for a short time or on a one-off basis for hunting activities. Experimental research suggests that specimens used as projectile weapons do not always show distinct use-wear traces (see, among others, BARTON, BERgMAN 1982; FisCHER et al. 1984; Odell, Cowan 1986; Dockall 1997; Kelterborn 2000; Dmochowski, Pyżewicz 2012). However, at this stage of the research there is no macro or microscopic usewear evidence on arrowheads from Ulów. At the same time, the aforementioned arrowheads show traces of storage in specific conditions. The above-mentioned location and morphology of use-wear indicate that these specimens were stored for a long time, and were transported in containers made of organic materials, mainly 

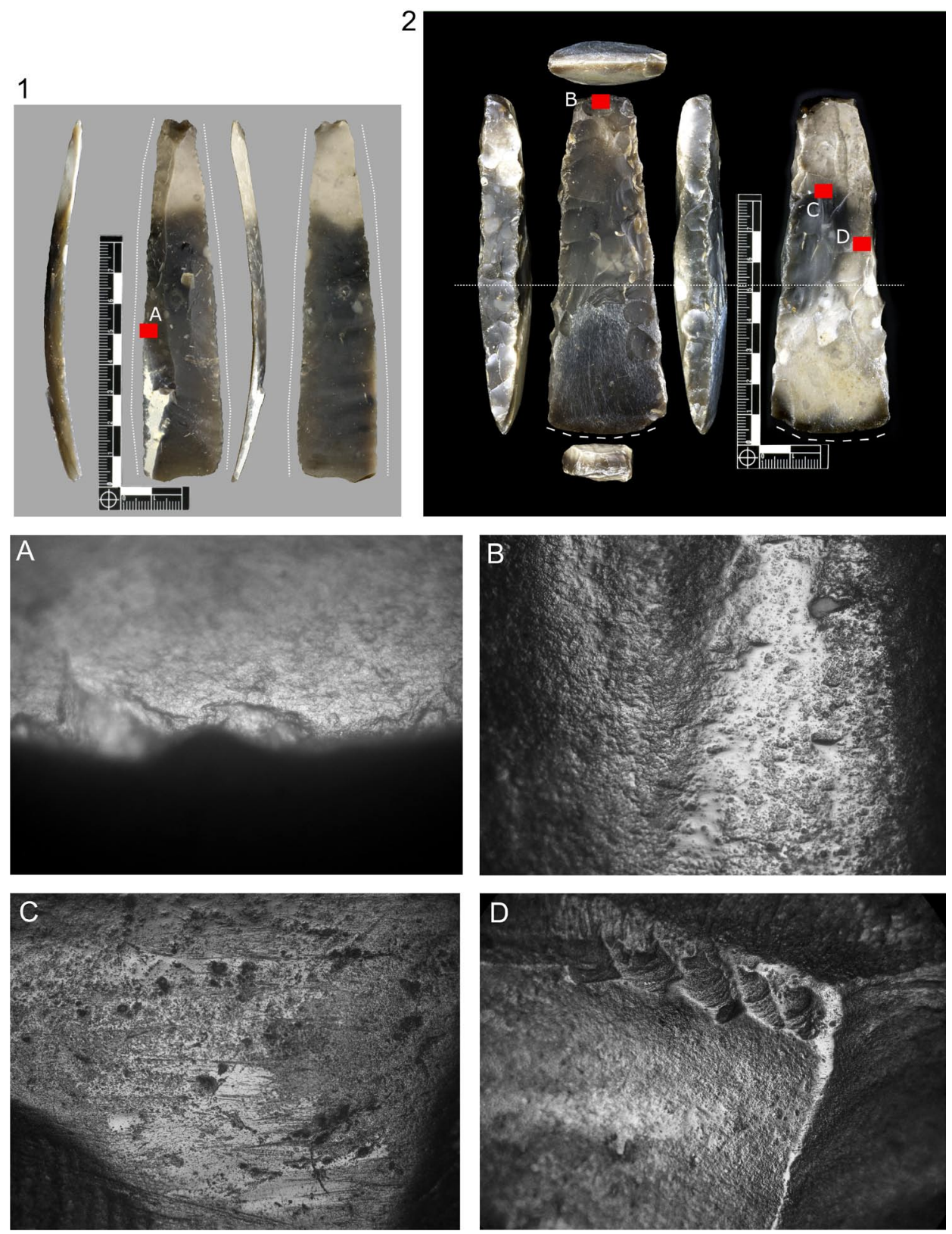

Fig. 6. Ulów, site 4. Flint artefacts from barrow II. 1 - retouched blade; 2 - axe. A - traces of contact with hide (storage/transport); B, D - traces of contact with hide /plant fibre (hafting); C - bright spot (hafting or postdepositional traces). A - 100× magnification; B-D - 50× magnification. Phot. T. Wiśniewski, K. Pyżewicz

hide, but most probably also plants. Such interpretations were confirmed by series of experimental tests (see, among others, BudZISZEwSKI, Tunia 2000: 122; PyżEwicz 2012; PyżEwICZ, GRUŻDź 2014). It should be added that the traces do not appear 

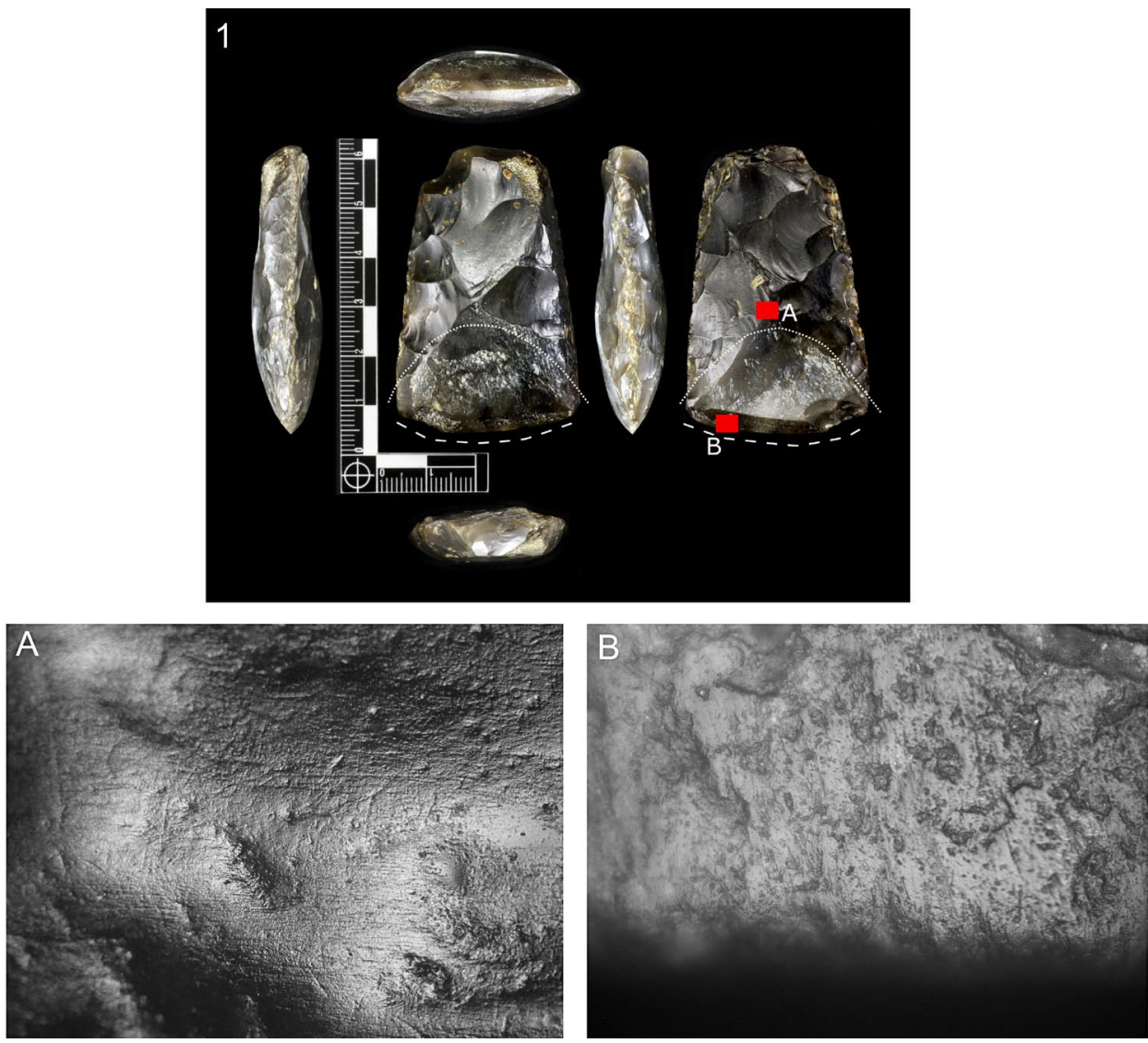

Fig. 7. Ulów, site 4. Flint artefact from barrow II. 1 - axe. A - traces of contact with hide /plant fibre (hafting); B - traces of wood chopping. A $-50 \times$ magnification; B $-200 \times$ magnification. Phot. T. Wiśniewski, K. Pyżewicz

on objects which were used for hunting activities, for instance, while arrowheads being taken out of an animal's carcass (among others DMochowski, Pyżewicz 2012; PyżEwICZ 2013b). Moreover, due to the specific location of traces on tips and barbs, it should be acknowledged that these objects were stored in quivers as components of arrows - as in such containers only the protruding parts of the objects are in direct contact with them (this is also suggested in other microscopic studies of arrowheads - i.a Marquez et al. 2008; PyżEwicz 2017). Arrowheads found at other sites (in Koniusza, Zielona and Dąbrowa Biskupia) of the Corded Ware Culture show similar traces. Some researchers relate the use-wear to hide processing or technological treatment (see, among others, DrobNiEWICZ 1979; WiniarsKa-KabaCiŃSKA 2007, BudziszewsKi et al. 2008). Such procedures include intentional dulling of barbs so that arrows could not be easily taken out of the hit target (see VAN GIJN 2010: 208, 209), or to stabilise arrowheads' haft and protect the sinew (CRABTrEe, DAVIS 1968; VAN GIJN 1990: 115). According to another interpretation, the use-wear 
could result from rubbing the blade against the hide in order to make hafting easier, and for more effective usage of the arrowheads (CASPAR et al. 1989; BUDZISZEWSKI et al. 2008: 48-51). The traces on single arrowheads forming the set of six, and obtained from both graves, clearly differ from the aforementioned types of traces. As the flint surfaces were slightly polished, both forms were most probably not hafted, and they could have been left loose.

Retouched blades from three barrows (I and III at site 3, and II at site 4), show similar marks which suggest that they were stored in organic sheaths made of soft materials (hide and/or plants), and show no use-wear traces or traces resulted from short-term processing of plants. Unfortunately, due to the poorly developed form of traces and their spotted morphology, the type of sheath cannot be determined. It should be added that a similar retouched blade from the grave of the Corded Ware Culture in Wilczyce revealed clear traces of plant processing stretching along one edge, while another edge had been hafted (WŁODARCZAK et al. 2016: 42, 43). It is conceivable that retouched blades from Ulów were treated in a similar way, which is indicated, at least partly, by traces found on one blade - along one of its longer edges the traces of contact with plants are clearer that in other cases. At the same time, it should be noted that similar retouched specimens of the Corded Ware Culture might have had a different function, and were hafted in a different way, for instance a set of blades from Zielona, which were used for cutting raw material of different hardness including hide, boring and polishing hard raw material, or used as a strike-a-light (WŁODARCZAK 2004: 30-32; WINIARSKA-KABACIŃSKA 2007). Additionally, there are some other examples of blades analyzed microscopically, which are associated with the Corded Ware complex and excavated from sites located in the more distant regions. These forms were unused or bear some traces of usage like examples of unretouched blades from burial from Vikletice, Czech Republic, which function was associated with plant processing (KNUTSSON 1995: 221-224). Moreover, there are some examples of blades from Western Europe which were treated in the similar way as artifacts from Ulów. The observed traces associated with hide and plants were resulted from storage and transport, and if they were used it was not intensively (VAN GIJN 2010: 142, 143). More sophisticated retouched long blades - French or Swiss daggers usually were used for cutting siliceous plant (i.a. ANDERSON et al. 1992; PLISSON et al. 2002; BEUGNIER, Plisson 2004; VAN GIJN 2010: 145-148). Simultaneously, lithic daggers are covered by intense traces of hafting which are similar to these created during the contact with plant, and sometimes hide. ANNELOU VAN GiJn (2010: 147) suggested that this configuration of traces could be resulted of using sheaths made of plaited siliceous plants or from bast. The contact of lithic with the bast creates polishes similar to hide. Simultaneously, the researcher underlined, that hide could be used as a part of some kind of sheaths in which lithic daggers were stored.

Unlike the above-mentioned forms of arrowheads and retouched blades, which do not show traces of long usage or repairs, the analysed axes bore particularly intense hafting, repairing and use-wear traces. The axes were deeply set in hafts made of wood and antlers, and the space between them was most probably lined with material 
of plant origin and/or hide. In considering the type of hafts should be taken into account the suggestion of using bast or plaited siliceous plants (mentioned above). The hafts most often reached the extension of the polished surface. Based on microscopic studies it can be suggested that examined axes could be set transversely or in parallel to the to the symmetry axis of the hafts, like some examples of finds from the Late Neolithic (MüLLER-BeCK 1965; SUTER 1993).

Groups of macroscopic grinding marks of the axes' blades indicate that these parts were probably polished many times (see, among others, WŁODARCZAK 2004: 26, 27; Pyżewicz 2013a; Pyżewicz et al. 2016). The axes from the Ulów graves were most probably used for wood chopping. However, the blade of at least one of them was polished before being deposited in the grave. It should be added that axes discovered in Zielona were also in use, yet it was not possible to determine their exact function (WINIARSKA-KABACIŃSKa 2007). Similar function of axes associated with wood processing or marks of re-sharpening before deposition of the tools in burials were observed on examples from Netherlands which are associated with the Corded Ware complex (VAN GIJN 2010: 143, 144; WentinK et al. 2011).

Among all specimens which underwent microscopic analysis there is another interesting type of functional object - a strike-a-light. In this case, the object was most likely formed in the Late Palaeolithic, and was later used by Neolithic groups in activities such as making a fire. The results of microscopic analysis of specimens from Dąbrowa Biskupia (BUDZISZEWSKI et al. 2008) and Zielona (WINIARSKA-KABACIŃSKA 2007) attest to such application of flint artefacts laid in graves of the societies of the Corded Ware Culture.

The results of the functional studies compared with spatial distribution of goods inside of the analysed graves (NIEZABITOWSKA-WIŚNIEWSKA, WIŚNIEWSKI 2011: fig. 8; NIEZABITOWSKA-WIŚNIEWSKA, WIŚNIEWSKI, in press, fig. 5) might suggest a couple of explanations regarding the treatment of lithics. In cases such as in barrow I and III from site Ulów 3 the blade was deposited near the axe on the side of the grave. This might indicate that both of these tools were part of the same tool kit and their had different roles. Additionally, the concentration of the arrowheads from barrow I from site Ulów 3 indicate that these artefacts were grouped together in the pouch or rather quiver. It is possible that the analysed lithic artefacts were carried on near to each other in daily activities which caused, among other things, the formation of the traces connected with the transport. Unfortunately, the state of preservation of features excludes more precise information about their localization within grave (unfortunately most of human bones have not been preserved). It should be added, that both equipment in the form of lithic knives (retouched blades) and arrowheads are characteristic for male burials (WŁodARCZAK 2004: 66, 67, 71, 72; NiEZABITOWSKA-WiŚNIEWSKA, WiŚNIEWSKI 2011; NIEZABITOWSKA-WIŚNIEWSKA, WIŚNIEWSKI, in press). These tool kit were located in barrow I and III from site Ulów 3 and barrow II from Ulów 4.

Acknowledgements. The work was funded by the National Science Centre (Poland) allocated for the project based on the decision number DEC-2013/09/B/HS3/03352. 


\section{SUMMARY}

All flint materials from three barrows (I, II, III) discovered at Ulów site 3, and one barrow (II) from Ulów site 4 underwent use-wear analysis. Three of them are characterised by similar tool kit (arrowheads, single retouched blades and axes), which are distinguished by the precision of workmanship and advanced flint technology. On the basis of the results of use-wear analysis, it should be acknowledged that arrowheads were elements of projectiles, and were carried in quivers for some period of time. Similar microscopic traces were found on blade forms, and it can be stated that they were stored in containers or sheaths. Only the axes show very intense hafting traces, and usually also use-wear traces. The situation is different when it comes to the inventory of another barrow (II, site 3), which is characterised by a variety of tools related to flint objects made on an ad hoc basis (mainly splintered forms).The only use-wear traces were recorded on a burin, which was used as a strike-a-light.

To sum up, it can be stated that it is possible that all presented specimens were used by individuals for some time, and were laid in their graves as grave goods. It should be added that use-wear analysis suggests a certain relationship between the type or morphology of the object and its function - less or more utilitarian, and possibly representative (as indicated by the characterand intensity of hafting and use-wear traces). Unfortunately, at this stage of the research it is impossible to determine the role of individual flint tools in the groups of the Corded Ware Culture, due to poor reference database.

\section{REFERENCES}

Anderson P., Plisson H., Ramseyer D., 1992. La moisson au Néolithique final: approche tracéologique d'outils en silex de Montilier et de Portalban. Archéologie Suisse 15(2): 60-67.

ANDERSON-GERFAUD P., 1988. Using prehistoric stone tools to harvest cultivated wild cereals: preliminary observations of traces and impact. In: Beyries S. (Ed.), Industries Lithiques: Tracéologie et Technologie. British Archaeological Reports - International Series 411. Oxford: 175-198.

Barton R. N. E., Bergman C. A., 1982. Hunters at Hengistbury: some evidence from experimental archaeology. World Archaeology 14(2): 237-248.

Beugnier V., Plisson H., 2004. Les poignards en silex du Grand-Pressigny: fonction de signe et fonctions d'usage. In : Constantin C., Bodu P. (Eds.), Approches fonctionnelles en Préhistoire, Actes du XXVe congrès préhistorique de France, Nanterre, 24-26 novembre 2000. Société préhistorique française, Paris: $139-154$.

Budziszewski J., Czeberszuk J., Winiarska-Kabacińska M., Chachlikowski P., 2008. Grób społeczności kultury ceramiki sznurowej z Dąbrowy Biskupiej, stan. 21, pow. Inowrocław, woj. kujawsko-pomorskie. In: BednarczyK J., CzebreszuK J., Makarowicz P., Szmyt M. (Eds.), Na pograniczu światów. Studia z pradziejów międzymorza bałtycko-pontyjskiego ofiarowane Profesorowi Aleksnadrowi Kośko w 60. rocznicę urodzin. Wydawnictwo Poznańskie, Poznań: 31-69.

Budziszewski J., Tunia K., 2000. A Grave of the Corded Ware Culture Arrowheads Producer in Koniusza, Southern Poland. Revisited. In: Kadrow S. (Ed.), A Turning of Ages. Jubilee Book Dedicated to Professor Jan Machnik on His $70^{\text {th }}$ Anniversary. Institute of Archaeology and Ethnology. Polish Academy of Sciences, Kraków: 101-135.

Caspar J.-P., Kaczanowska M., Kozlowski J.K., 1989. Chipped stone industries of the Linear Band Pottery Culture (LBP): Techniques, morphology and function of the implements in Belgian and Polish Assemblages. Helinium 29(2): 157-205.

Crabtree D. E., Davis E., 1968. Experimental manufacture of wooden implements with tools of flaked stone. Science 159: 426-248. 
Dмосноwsкi P., PyżEwicz K., 2012. Łucznictwo eksperymentalne. Rola doświadczeń w aspekcie analiz technologicznych i funkcjonalnych na przykładzie wybranej sytuacji źródłowej z mezolitu. In: GANCARSKi J. (Ed.), Skanseny archeologiczne i archeologia eksperymentalna. Muzeum Podkarpackie w Krośnie, Krosno: 497-528.

Dockall J. E., 1997. Wear traces and Projectile Impact: A Review of the Experimental and Archaeological Evidence. Journal of Field Archaeology 24(3): 321-331.

DrobNiEwicz B., 1979. Analiza traseologiczna wyrobów krzemiennych z cmentarzyska kultury ceramiki sznurowej w Koniuszy, woj. Kraków. Sprawozdania Archeologiczne 31: 91-94.

Fischer A., Vemming Hansen P., Rasmussen P., 1984. Macro and Micro Wear Traces on Lithic Projectile Points. Experimental Results and Prehistoric Examples. Journal of Danish Archaeology 3: 19-46.

Howard C. D., 1999. Amorphous Silica, Soil Solutions, and Archaeological Flint Gloss. North American Archaeologist 20(3): 209-215.

Juel Jensen H., 1988. Functional Analysis of Prehistoric Flint Tools by High-Power Microscopy: A Review of West European Research. Journal of World Prehistory 2(2): 53-87.

Juel JENSEN H., 1994. Flint tools and plant working. Hidden traces of stone age technology. A use wear study of some Danish Mesolithic and TRB implements. Aarhus University Press, Aarhus.

Keeley L. H., 1980. Experimental Determination of Stone Tool Uses. A Microwear Analysis, University of Chicago Press, Chicago.

Kelterborn P., 2000. Analysen und Experimente zu Herstellung und Gebrauch von Horgener Pfeilspitzen. Jahrbuch der Schweizerischen Gesellschaft für Ur- und Frühgeschichte 83: 37-64.

KNUTSSON K., 1995. Funktionsanalys av flintspan fran stridsyxegravar i Vikletice, Tjeckiska repuhliken. In: Knutsson H., Slutvandrat. Aspekter pa overgangen fran rorlig till bofast tillvaro. Societas Archaeologica Upsaliensis, Uppsala: 221-224.

Korobкоwa G. F., 1999. Narzędzia w pradziejach. Podstawy badania funkcji metodą traseologiczną. Wydawnictwo Naukowe Uniwersytetu Mikołaja Kopernika, Toruń.

KuBICKi R. Ł., 2015. Finalna obróbka krzemiennych siekier i narzędzi siekieropodobnych. Studium eksperymentalne. Folia Praehistorica Posnaniensia 20: 257-275.

Levi-Sala I., 1993. Use-Wear Traces: Process of Development and Post-depositional alterations. In: Anderson P. C, Beyries S., Otte M., Plisson H. (Eds.), Traces et fonction, les gestes retrouvés. Actes du colloque international de Liège, 8-9-10 décembre 1990. ERAUL 50. Service de Préhistoire, Université de Liège, Liège: 401-416.

Levi-Sala I., 1996. A Study of Microscopic Polish on Flint Implements. British Archaeological Reports - International Series 629. Oxford.

Malecka-KuKawka J., 2001. Między formą a funkcją. Traseologia neolitycznych zabytków krzemiennych z ziemi chełmińskiej. Wydawnictwo Naukowe Uniwersytetu Mikołaja Kopernika, Toruń.

Marquez B., Gibaja J. F., Gonzalez J. E., Ibañez J. J., Palomo A., 2008. Projectile points as signs of violence in collective burials during $4^{\text {th }}$ and $3^{\text {rd }}$ millennia cal. $\mathrm{BC}$ in the North-East of the Iberian peninsula. In: Longo L., Skakun N. (Ed.), "Prehistoric Technology" 40 Years Later: Functional Studies and the Russian Legacy. Proceedings of the International Congress Verona (Italy), 20-23 April 2005. British Archaeological Reports - International Series 1783. Oxford: 321-326.

Moss E., 1983. The Functional Analysis of Flint Implements. Pincevent and Pont d'Ambon: Two Cases from the French Final Paleolithic. British Archaeological Reports - International Series 177. Oxford.

MüLLER-Beck H., 1965. Seeberg. Burgäschisee-Süd. Teil 5. Holzgeräte und Holzbearbeitung. Acta Bernensia II. Stämpfli, Bern.

NiEZABiTOWSKA-WiŚNIEWSKA B., WiŚNIEWSKI T., 2011. Kurhany kultury ceramiki sznurowej na stanowisku 3 w Ulowie, powiat tomaszowski. In: Kowalewska-Marszalek H., WŁodarczaK P. (Eds.), Kurhany 
i obrządek pogrzebowy w IV-II tysiącleciu p.n.e. Instytut Archeologii i Etnologii Polskiej Akademii Nauk; Instytut Archeologii Uniwersytetu Warszawskiego, Kraków, Warszawa: 329-369.

NieZabitowska-WiŚniewska B., WiŚNIEWski T., in press. Ulów, site 3. A new barrow of the Corded Ware Culture in Middle Roztocze (south-eastern Poland).

Odell G. H., Cowan F., 1986. Experiments with Spears and Arrows on Animal Target. Journal of Field Archaeology 13(2): 195-211.

Plisson H., Mallet N., Bocquet A., Ramseyer D. 2002. Utilisation et rôle des outils en silex du GrandPressigny dans les villages de Charavines et de Portalban (Néolithique final). Bulletin de la Société préhistorique française 99(4): 793-811.

Pyżewicz K., 2012. Tropem mezolitycznych łowców. Interpretacja funkcji zbrojników z wybranych stanowisk. Fontes Archaeologici Posnanienses 48: 95-108.

Pyżewicz K., 2013a. Analiza traseologiczna materiałów krzemiennych. In: PrzybyŁa M. M., SzczePanek A., WŁodarczaK P. (Eds.), Koszyce, stanowisko 3. Przemoc i rytuał u schyłku neolitu. Stowarzyszenie Archeologów Terenowych „Stater”, Wydawnictwo i Pracownia Archeologiczna PROFIL-ARCHEO Magdalena Dzięgielewska, Kraków-Pękowice: 179-202.

Pyżewicz K., 2013b. Inwentarze krzemienne społeczności mezolitycznych w zachodniej części Niżu Polskiego. Analiza funkcjonalna. Wydawnictwo Fundacji Archeologicznej, Zielona Góra.

PyżEwicz K. 2017. Materiały krzemienne z cmentarzyska ludności kultury mogiłowej w Górzycy. In: Socha K., Sójkowska-Socha J. (Eds.), Górzyca. Birytualne cmentarzysko ludności kultury mogiłowej nad środkową Wartą. Wydawnictwo Fundacji Archeologicznej w Zielonej Górze, Kostrzyn nad Odrą: 267-282.

PyżEwicz K., GrużDź W., 2014. Possibilities of identifying transportation and use-wear traces of Mesolithic microliths from the Polish Plain. In: Marreiros J., Bicho, GiBAJA BAO J. (Eds.), International Conference on Use-Wear Analysis. Use-Wear 2012. Cambridge Scholars Publishing, Newcastle upon Tyne: 479-487.

PyżEwicz K., GrużDź W., DMochowski P., 2016. Lokalna wytwórczość form czworościennych w Wielkopolsce. Wstęp do problematyki. In: Borkowski W., SalaciŃsKa B., SalaciŃsKi S. (Ed.), Krzemień narzutowy w pradziejach. Materiały z konferencji w „Mądralinie” w Otwocku, 18-20 października 2010. Studia nad Gospodarką Surowcami Krzemiennymi w Pradziejach 8. Państwowe Muzeum Archeologiczne w Warszawie, Warszawa: 309-341.

PyżEwicz K., RozbiEgalski P., 2012. Sposoby rozpalania ognia w młodszej epoce kamienia na terenie ziem polskich w kontekście badań eksperymentalno-traseologicznych. Światowit, Fascykuł B, Archeologia pradziejowa i średniowieczna. Archeologia Polski 9(50): 259-272.

Rотs V., 2003. Towards an understanding of hafting: the macro- and microscopic evidence. Antiquity 77 : 805-815.

Rots V., 2008a. Hafting and raw materials from animals. Guide to the identification of hafting traces on stone tools. Anthropozoologica 43: 43-66.

Rots V., 2008b. Hafting traces on flint tools. In: Longo L., Skakun N. (Ed.), "Prehistoric Technology" 40 Years Later: Functional Studies and the Russian Legacy. Proceedings of the International Congress Verona (Italy), 20-23 April 2005. British Archaeological Reports - International Series 1783. Oxford: $75-84$.

Rots V., 2009. The functional analysis of the Mousterian and Micoquian assemblages of Sesselfelsgrotte, Germany: Aspect of tool use and hafting in the European Late Middle Paleolithic. Quartär 56: 37-66.

Rots V., 2010. Prehension and Hafting Traces on Flint Tools. A Methodology. Leuven University Press, Leuven.

Rots V., VermeErsch P. M., 2004. Experimental characterization of hafting traces and their recognition in archaeological assemblages. In: Walker E. A., Wenban-Smith F., Healy F. (Ed.), Lithics in Action. Papers from the Conference "Lithic Studies in the Year 2000". Oxbow, Oxford: 156-168. 
Suter P. J., 1993. Holme, Hirschgeweihfassungen und Steinbeilklingen. Gedanken zur Entwicklung des neolithischen Beilen im schweizerischen Mitteland. Jahrbuch der Schweizerischen Gesellschaft für Ur- und Frühgeschichte 76: 27-44.

Van Gijn A. L., 1990. The Wear and Tear of Flint. Principles of Functional Analysis to Dutch Neolithic Assemblages. Analecta Praehistorica Leidensia 22.

Van Gijn A. L., 2010. Flint in focus. Lithic Biographies in the Neolithic and Bronze Age. Sidestone Press, Leiden.

Vaughan P.C., 1985. Use-Wear Analysis of Flaked Stone Tools. University of Arizona Press, Tucson.

Wentink K., Van Gijn A., Fontijn D., 2011. Changing contexts, changing meanings: Flint axes in Middle and Late Neolithic communities in the northern Netherlands. In: DAVIs V., EdmondS M. (Eds.). Stone Axe Studies 3. Oxbow, Oxford: 399-408.

WiniarsKa-KabaciŃsKa M., 2007. Przywódca neolityczny z Zielonej. Badania traseologiczne. In: Dzieduszycki W., Wrzesiński J. (Ed.), Środowisko pośmiertne człowieka. Funeralia Lednickie, Spotkanie 9. Stowarzyszenie Naukowe Archeologów Polskich, Poznań: 169-175.

WiNIARSKA-KABACIŃSKA M., 2008. Functional analysis as a tool for the interpretation of mortuary practices. A case-study of the Corded Ware Culture graves at Zielona, southern Poland. In: Longo L., Skakun N. (Ed.), "Prehistoric Technology" 40 Years Later: Functional Studies and the Russian Legacy. Proceedings of the International Congress Verona (Italy), 20-23 April 2005. British Archaeological Reports - International Series 1783. Oxford: 331-335.

WŁodarczaK P., 2004. Kultura ceramiki sznurowej na Wyżynie Małopolskiej. Instytut Archeologii i Etnologii Polskiej Akademii Nauk, Karków.

Wlodarczak P., Boroń T., Kurzawska A., Osypińska M., Szczepanek A., Winiarska-KabacińsKa M., 2016. Grób kultury ceramiki sznurowej ze stanowiska $10 \mathrm{w}$ Wilczycach, pow. sandomierski. Przegląd Archeologiczny 64: 29-57. 